ORIGINAL ARTICLE

\title{
The Relationship Between Galen's Personality Type Theory and Emotional Intelligence Level
}

\author{
Olyvia Sita Aldisa Thadea ${ }^{1}$, Suhartono Taat Putra ${ }^{2}$, I Gusti Ngurah Gunadi Sindhu \\ Putra $^{3 *}$ \\ ${ }^{1}$ Faculty of Medicine, Universitas Airlangga, Surabaya, Indonesia \\ ${ }^{2}$ Graha Masyarakat Ilmiah Kedokteran (GRAMIK) Faculty of Medicine, Universitas Airlangga, Surabaya, Indonesia \\ ${ }^{3}$ Department of Psychiatric, Faculty of Medicine, Universitas Airlangga - Dr. Soetomo General Hospital, Surabaya, \\ Indonesia
}

\author{
A R T I C L E I N F O \\ Article history: \\ Received 28 September 2018 \\ Received in revised form 25 \\ October 2018 \\ Accepted 29 October 2018 \\ Available online 30 November \\ 2018 \\ Keywords: \\ Personality Type, \\ Galen's Theory, \\ Emotional Intelligence, \\ Preclinical Medical Student. \\ *) Corresponding author: \\ ngurah.gunadi@fk.unair.ac.id
}

\begin{abstract}
A B S T RA C T
Introduction: Personality is a behavior and mindset pattern that is typical for each person in responding to every event or stimulus in his environment. Galen's theory has classified personality types into four types they are Sanguinis, Choleric, Melancholy, and Plegmatis. The level of emotional intelligence shows a person's ability to deal with demands and pressures to achieve their best in thinking and behaving appropriately. This study aims to prove the relationship between personality types based on Galen's theory with emotional intelligence level in preclinical medical students.

Methods: This study is a comparative study using an online questionnaire instrument on emotional intelligence and personality type tests compiled by Florence Littauer. This research variables are the emotional intelligence level and personality type. This study used data from 100 respondents, then data was analyzed using Chi Square test.

Results: From 100 respondents, dominant personality type is Sanguinis $35 \%$, followed by Choleric $13 \%$, Melancholy $27 \%$, and Plegmatis $25 \%$. There were no respondent who showed a low level of emotional intelligence in this study. $64 \%$ of respondents have a high level of emotional intelligence, while the remaining $36 \%$ have a moderate level. Chi Square test shows $\mathrm{p}$ value is 0.032 .

Conclusion: There is a relationship between personality types based on Galen's theory with emotional intelligence level on medical students in Faculty of Medicine, Universitas Airlangga.
\end{abstract}

\section{Introduction}

Personality is a behavior and mindset pattern that is typical for each person in responding to every event or stimulus in his environment. ${ }^{1}$ Florence Littauer (1996) adapted Galen's theory of human personality type, Galen classifies human personality in four types, namely sanguinis, choleric, melancholy, and Phlegmatic. Sanguinis are types that are fun, sociable, and have great energy. Choleric is the type that has great desire and very goal oriented. Melancholy is a thinker and perfectionist type. While Phlegmatic is the observer type who is calm and does not like the crowd. Each type has strengths and weaknesses. ${ }^{2}$
Emotional intelligence works synergistically with intellectual intelligence and social intelligence. Emotional intelligence is a noncognitive skills that affect the ability to overcome demands and pressure. Salovey and Mayer, the first users of the term emotional intelligence, revealing five aspects of emotional intelligence, they are self-awareness, self-regulation, empathy, motivation, and social skills. ${ }^{3}$ Factors affecting emotional intelligence consist of internal and external factors. Those internal factors are the limbic system and the neocortex in the brain. External factors consist of family and non-family environment factors. ${ }^{4}$ 
Future doctors also require ability in communication, teamwork, clinical decision making, and the implementation of medical ethics. ${ }^{5}$ Medical students are expected to communicate well with patients so that they can diagnose and treat patients correctly according to the medical ethics. A person who works in the community including doctors also has the responsibility to motivate and deliver knowledge as well. Doctors are also close to emergency situations so they must be able to work under pressure and keep positive thought to help their patients. Some examples of these responsibilities show that good and successful doctors must also have the skills to behave, socialize and manage their emotions. The base of these capabilities can be formed through a long process of study. ${ }^{6}$

Emotional intelligence has generally been found to have large significant correlations with personality type. Personality and emotional intelligence also could affect the behavior and mindset of the preclinical medical students and in the future forming into skill and action of doctors. $^{7}$

This study aims to prove the relationship between personality types based on Galen's theory with emotional intelligence level in preclinical medical students of Faculty of Medicine, Universitas Airlangga in the year of 2014. In detail, this study aims to determine the distribution of personality types and emotional intelligence level in students as well as differences of emotional intelligence level in each personality type.

\section{Methods}

This study was a comparative analytical research method with a cross-sectional approach. The population used is preclinical medical student in 2014 of Faculty of Medicine, Universitas Airlangga. The samples were students who studying in third fifth, and seventh semester. The sample size was obtained by using proportional random sampling to obtain 36 students of seventh semester, 35 students of fifth semester, and 29 students of third semester.

The research variables were personality type and emotional intelligence level. Data taken for personality type variables came from the theory personality type test compiled by Florence Littauer, and emotional intelligence used Likert scale of emotional intelligence questionnaire. The results of descriptive analysis of the data will show the distribution semester and sex variables for each personality type and also emotional intelligence level by calculating absolute and relative frequencies. Comparative analysis of data conducted by using Chi Square test.

\section{Results}

\section{Characteristics of Respondents}

This study involved 100 students from class of 2012, 2013, and 2014 as respondents. Respondents from class of 2012 were 36 people, class of 2013 were 35 people, while from class of 2014 were 29 people. Distribution by gender was 79 females and 21 males.

The reliability test results of the Likert's Scale Emotional Intelligence Questionnaire using the Alpha Cronbach test stated that the questionnaire had a high reliability coefficient $(0.858)$. Validity test was done by using correlation coefficient formula, obtained the results of 21 out of 60 items, the questionnaire statement was considered invalid because its $r$ value was less than $r$ table (0.165).

\section{Distribution of Personality Types based on Galen's Theory}

Table 1. The Distribution of Personality Type based on Classes in Preclinical Medical Students of Universitas Airlangga.

\begin{tabular}{llllll}
\hline \multirow{2}{*}{$\begin{array}{l}\text { Class } \\
\text { of }\end{array}$} & \multicolumn{5}{c}{ Personality Type } \\
\cline { 2 - 5 } & $\begin{array}{l}\text { Sangu } \\
\text { inis }\end{array}$ & $\begin{array}{l}\text { Chole } \\
\text { ric }\end{array}$ & $\begin{array}{l}\text { Melan } \\
\text { choly }\end{array}$ & $\begin{array}{l}\text { Phleg } \\
\text { Matic }\end{array}$ & Total \\
\hline 2012 & 8 & 4 & 13 & 11 & 36 \\
$(\%)$ & 22,2 & 11,1 & 36,1 & 30,6 & 100,0 \\
2013 & 12 & 7 & 10 & 6 & 35 \\
$(\%)$ & 34,3 & 20,0 & 28,6 & 17,1 & 100,0 \\
2014 & 15 & 2 & 4 & 8 & 29 \\
$(\%)$ & 51,7 & 6,9 & 13,8 & 27,6 & 100,0 \\
Total & 35 & 13 & 27 & 25 & 100 \\
$(\%)$ & 35,0 & 13,0 & 27,0 & 25,0 & 100,0 \\
\hline
\end{tabular}

The results showed that seventh semester preclinical medical students were dominated by melancholy personality types $(36.1 \%)$ while the fifth and third semester were dominated by sanguinis type (each $34.3 \%$ and $51.7 \%$ ). In general, the personality type that dominates was sanguinis type (35\%). Sanguinis and choleric personality types has similarity, namely extroverted character, while melancholy and Phlegmatic personality types have similarity, namely introverted character. Overall, introverted personality dominates (52\%), although only slightly higher than extroverts. Seventh semester students had more introverted personality $(66.7 \%)$ while for the fifth and third semester students personality dominated by extroverted personality, $54.3 \%$ and $58.6 \%$ respectively. Based on Galen's theory, further grouped based on extroverted and introverted personality, male students are dominated by extroverted personality types (sanguinis and choleric) (61.9\%), while female students are dominated by introverted personality types (melancholy and phlegmatic) (55.7\%).

\section{Distribution of Emotional Intelligence Levels}


Table 2. The Distribution of Emotional Intelligence Level based on Classes in Preclinical Medical Students of Universitas Airlangga

\begin{tabular}{lllll}
\hline \multirow{2}{*}{ Classes of } & \multicolumn{2}{l}{ Emotional Intelligence Level } & \multirow{2}{*}{ Total } \\
\cline { 2 - 4 } & Low & Moderate & High & \\
\hline 2012 & 0 & 13 & 23 & 36 \\
$(\%)$ & 0 & 36,1 & 63,9 & 100,0 \\
2013 & 0 & 12 & 23 & 35 \\
$(\%)$ & 0 & 34,3 & 65,7 & 100,0 \\
2014 & 0 & 11 & 18 & 29 \\
$(\%)$ & 0 & 37,9 & 62,1 & 100,0 \\
Total & 0 & 36 & 64 & 100 \\
$(\%)$ & 0 & 36,0 & 64,0 & 100,0 \\
\hline
\end{tabular}

Table 3. The Distribution of Emotional Intelligence Level based on Gender in Preclinical Medical Students of Universitas Airlangga

\begin{tabular}{lllll}
\hline \multirow{2}{*}{ Gender } & \multicolumn{3}{c}{ Emotional Intelligence Level } & \multirow{2}{*}{ Total } \\
\cline { 2 - 4 } & Low & Moderate & High & \\
\hline Male & 0 & 12 & 9 & 100 \\
$(\%)$ & 0 & 57,1 & 42,9 & 100 \\
Female & 0 & 24 & 55 & 100 \\
$(\%)$ & 0 & 30,4 & 69,6 & 100 \\
\hline
\end{tabular}

From the tables above, this study shows no respondents had a low level of emotional intelligence. All respondents from all semester dominantly has high level of emotional intelligence which seen in general for $64 \%$ and each group was above $60 \%$, while the percentage of moderate emotional intelligence level was $36 \%$. Male respondents tend to have moderate emotional intelligence level $(57.1 \%)$. On the other hand, female respondents were more likely to have high emotional intelligence level (69.6\%).

\section{Data analysis}

Chi square test is used to analyze the results of this study because the data is not normally distributed and it has categorical scale. Sanguinis personality type owned the highest score percentage of emotional intelligence compared to other personality $(40.6 \%)$. The comparative analysis showed there was a difference in emotional intelligence level for each group $(\mathrm{p}=0.032)$.

\section{Discussion}

This research showed that based on Galen's theory, the dominant personality type is sanguinis type. Sanguinis type has several advantages in its basic character, including: attracting the attention of many people, cheerful, optimistic, talkative, and enthusiastic. Often found the most problem that the community complained regarding health services is related to communication problems. ${ }^{8}$ complain about doctors who are more silent, do not provide an explanation, use medical terms that are not understood, which lead into miscommunication between doctor and patient. Students with sanguinis personality types have advantages in communication so that problems related to miscommunication between doctor-patient are expected to be avoided.

There are 13 respondents with choleric personality. This type has the potential for leadership. A choleric has a dynamic soul and high motivation. ${ }^{9}$ This is necessary in the professionalism attitude as a doctor. The choleric type is the type that does not hesitate in deciding something and likes challenges. The ability to make quick decisions is necessary for a doctor. Medical students are expected to be a strong doctor in facing the challenges of their profession. . While $27 \%$ of respondents had melancholy personality. This type is a person with the ability to understand others feeling and also have deep analytical thinking. ${ }^{9}$ This ability makes doctors have empathy for patients. Doctors are also expected to have a sense of empathy in addition to being able perform effective communication. ${ }^{8}$ Melancholy students are expected to be able make patients comply with the treatment provided. A melancholy doctor also sees a disease as a holistic condition.

Another 25 respondents were found to have Phlegmatic personality types. People with this personality type tend to avoid conflict, patience, calm, and such a good listener. The Phlegmatic type can also be a good mediator in a problem through its logical and objective thinking. ${ }^{9}$ This can make Phlegmatic students have the ability to hear patient complaints well and try to be professional in accordance with the medical ethics in order to not cause conflict between doctors and patients.

Overall, male respondents had extroverted personality $(61.9 \%)$, while female students were dominated by introverted personality (55.7\%). Table 3 shows that both men and women are dominated by sanguinis type. Several studies show that men and women have different adaptive coping abilities. ${ }^{10}$ Men tend to use problem-focused strategies while women tend to use emotion-focused strategies. Problem-focused strategies aim to overcome stressors by changing the stressor itself. Emotion-focused strategies address stressors by tolerating themselves against stressors. Usually this type is used by individuals who feel that the stressor cannot be changed. ${ }^{11}$ Adaptive coping strategies in women show that women have a tendency to suppress their emotions in dealing with stressors and this is related to introverted personality. ${ }^{10}$ This statement supports the results of this study that women tend to have introverted personalities.

The results in this study indicate that medical students in Faculty of Medicine Universitas Airlangga tend to have high emotional intelligence level, total of 64 out of 100 respondents had high level of emotional intelligence. While the rest shows a moderate level. The level of emotional intelligence in this study shows the level of individual ability to motivate themselves, resist frustration, control impulses, regulating moods, maintain stress, and empathy of medical students. Aspects assessed in the questionnaire used were self-awareness, self-regulation, motivation, empathy, and social skills. ${ }^{10}$ Indonesian Medical Code of Ethics in 2012, article 2 
written "A doctor must always make professional decisions independently and maintain professional behavior in the highest measure". The passage further explanation that a professional medical decision making is aiming at attitudes, actions, and behavior of doctors as a manifestation of moral integrity, intellectual honesty, and altruistic ethical component of a professional standard. Doctors must have the ability to manage emotions in motivating themselves, showing empathy, and applying social skills. ${ }^{5}$

This study showed that female had higher emotional intelligence level compared to men. This has different results from the study in Pakistan that showed men have higher emotional intelligence level than women but have similarities with the results of research conducted in Alabama that suggested women get higher emotional intelligence scores because they have better empathy, self-awareness, and self-regulation than men. Previous study by Tapia and Dunn also supports the conclusions because women have a sense of empathy, social responsibility, and a better quality of interpersonal relationships. The superiority of women in these various aspects makes women's emotional intelligence levels higher than men. ${ }^{12}$

Teenage girls have a higher oxytocin hormone than men. This makes young women have a higher interest in interpersonal relationships. The high intensity of dealing with other people makes girls more dependent on others, then tends to be sensitive to rejection and often dissatisfied with interpersonal relationships. On the other hand, men are different from women. They are more aggressive and show lot emotion than women. This supports the results of this study that men have more extroverted personality than women. ${ }^{13}$ Women have a tendency to suppress their emotions in dealing with stressors because most of them also have introverted personalities. Aspects of self-awareness, self-regulation, and interpersonal relationships are the main keys in explaining the personality of women who tend to be introverted but have higher emotional intelligence. ${ }^{12}$ Apart from the gender factors, high emotional intelligence level is expected could maintain professional behavior in the highest measure as stated in the Medical Code of Ethics.

The Chi Square test indicated a statistically differences of emotional intelligence level in each personality type based on Galen's theory $(p=0.032)$. Sanguinis types have the highest emotional intelligence level percentage $(40.6 \%)$. Phlegmatic personality types on the contrary, show the highest percentage of moderate emotional intelligence. The results of these difference show that there is a relationship between personality types based on Galen's theory and the level of emotional intelligence.

Sanguinis and phlegmatic are personality types that have similarities, namely stable emotions. The difference between sanguinis and Phlegmatic types is the extroverted-introverted dimension. Sanguinis is an extroverted personality while phlegmatic is an introvert. ${ }^{9}$
Social skills possessed better by extroverted individuals than introverts. Sanguinis as extroverts have better social support compared to phlegmatic, so this statement supports the results of this study. Sanguinis have one of lively's trait (full of hope, strong, and passionate). ${ }^{14}$ which shows that this type has good self-motivation ability. The statement relates to the aspects of selfmotivation of emotional intelligence that higher than Phlegmatic. Melancholy and choleric are personality types with poor emotional stability based on diagrams from Eysenck (1985). ${ }^{14}$ Both types should have low emotional intelligence level than Sanguinis and Phlegmatic, but this research does not prove it.

The instrument to measure emotional intelligence used in this study has limitation, because quite a lot of items are declared invalid after being tested for its validity. Correlation analysis between personality types and emotional intelligence aspects also cannot be done. This study also did not examine the various factors that influence emotional intelligence. The background regarding family and non-family environments besides educational institutions was also not considered in the processing of data, such as origin, religion, or certain tribes that could affect environmental factor. Data regarding internal factors from respondents regarding brain function were also not collected. IQ or intellectual intelligence can be a data to show the state of the brain's function of the respondent. IQ can show broadly the relationship of the neocortex with the limbic system, functioning properly or not, although in various studies it has not been proven directly about the relationship of IQ to the level of emotional intelligence. The existence of these various factors resulting in bias in this study.

\section{Conclusion}

The most dominant personality type of medical students in the Faculty of Medicine, Universitas Airlangga was the sanguinis type. There are differences in the level of emotional intelligence in each personality type based on personality types according to the Galen theory. The difference emotional intelligence level is showed high in the sanguinis and Phlegmatic types.

\section{Conflict of Interest}

The author stated there is no conflict of interest.

\section{References}

1. Friedman H and Schustack M. Kepribadian: Teori Klasik dan Riset Modern Edisi Ketiga Jilid 1. Translated from Personality: Classis Theories and Modern Research led. Jakarta: Penerbit Erlangga, 2008.

2. Littauer F. Personality Plus. Jakarta: Karisma, 2011.

3. Goleman D. Emotional Intelligence. Jakarta: Gramedia Pustaka Utama, 2007.

4. Hughes and Thompson. Handbook for Developing Emotional and Social Intelligence: Best practice, Case Studies, and Strategies. San Fransisco: Pfeiffer, 2009. 
5. IDI. Surat Keputusan PB IDI No. 111/PB/A.4/02/2013.Kode Etik Kedokteran Indonesia. In: Indonesia PBID, (ed.). Jakarta2013.

6. Lusiana M. Hubungan Tipe Kepribadian dengan Prestasi Akademik pada Mahasiswa Fakultas Kedokteran Universitas Riau Angkatan 2006. Jurnal Ilmu Kedokteran. 2009; 3: 59-66.

7. Austin EJ, Saklofske DH and Egan V. Personality, Wellbeing and Health Correlates of Trait Emotional Intelligence. Personality and Individual Differences. 2005; 38: $547-58$.

8. Adhani R. Etika dan Komunikasi Dokter-PasienMahasiswa. Banjarbaru: Grafika Wangi Kalimantan, 2008.

9. Littauer F. Personality Plus. Jakarta: Karisma, 2011.

10. Saptoto R. Hubungan Kecerdasan Emosi dengan Kemampuan Coping Adaptif. Jurnal Psikologi. 2010; 37: 13-22.

11. Cotton D. Stress Management: An Integrated Approach to Therapy. New York: Brunner/Mazel, 2013.

12. Summiya A, Hayat B and Khan SA. Emotional Intelligence and Gender Differences. Sarhad Journal of Agriculture. 2009; 25: 127-30.

13. Darmayanti N. Meta-Analisis: Gender dan Depresi pada Remaja. Jurnal Psikologi. 35: 164-80.

14. Angeles K. The Forgotten Personality. College Now Southwest Minnesota University, 2011. 